\title{
Chromosome Segregation in Hybrids between Extracted AABB Tetraploids and Common Wheat Varieties
}

\author{
P. J. Kaltsikes, L. E. Evans and E. N. Larter \\ Department of Plant Science, The University of Manitoba, \\ Winnipeg, Canada
}

Received February 7, 1969

\section{Introduction}

Several investigators (Jenkins and Thompson 1930, Joppa 1967, Kihara and Matsumura 1942, Love 1940, Thompson and Cameron 1928, Thompson 1934) examined chromosome segregation and its causes in pentaploid hybrids between tetraploid and hexaploid wheat species. They all found a preponderance of parental types in the progeny contrary to theoretical expectations and attributed this to a variety of reasons. It was not possible hitherto, however to ascertain the relative role of autonomous univalent control or influence of the background genotype in governing univalent elimination.

Kaltsikes et al. (1968) by using Kerber's method (Kerber 1964) extracted the AABB tetraploid component from three varieties of common wheat. This material provided the means of eliminating one of the variables of the problem of univalent elimination by placing the univalents of these varieties in a common genetic background. In addition, possible varietal differences and deviations from theoretical expectations and their causes could be studied. To accomplish this the present study was undertaken.

\section{Materials and methods}

The origin of the material used in the present study was described by Kaltsikes et al. (1968). All material for cytological studies was grown in the greenhouse where the average temperature was $21^{\circ} \mathrm{C}$. At least ten plants from each line were examined, unless otherwise indicated. For the study of mitotic chromosome numbers, root-tips were collected in ice water and were placed at $0^{\circ} \mathrm{C}$ for twenty-four hours following which they were transferred into a solution of three parts ethyl alcohol and one part glacial acetic acid. They were hydrolyzed in $1 \mathrm{~N} \mathrm{HCl}$ at $60^{\circ} \mathrm{C}$ for seven minutes, stained in Feulgen and counterstained in $0.5 \%$ acetocarmine. For meiotic studies, inflorescences were collected in Carnoy's solution and stained in $1.5 \%$ acetocarmine.

Data were compared by analysis of variance using a completely random design. All values were transformed according to the formula $\sqrt{\mathrm{X}+0.5}$ (Steel and Torrie 1960). Means were compared by $L s d$ and are reported in the 
original form. In all cases data were tested for homogeneity before pooling. The following hybrids were examined: Prelude $\times$ Prelude AABB, Rescue $\times$ Rescue $\mathrm{AABB}$, Thatcher $\times$ Thatcher $\mathrm{AABB}$, Rescue $\times$ Thatcher AABB, Thatcher $\mathrm{AABB} \times$ Rescue, Thatcher $\times$ Rescue $\mathrm{AABB}$ and Rescue AABB $\times$ Thatcher.

\section{Results}

\section{Hybrids between extracted $A A B B$ tetraploids and their $A A B B D D$ counterparts}

The results of the meiotic studies of the three pentaploid hybrids are summarized in Table 1. Figures 1-16 show representative cells of the

Table 1. Meiotic characteristic of pentaploid hybrids obtained from crosses between hexaploid (AABBDD) parent wheats and their extracted (AABB) tetraploid derivatives.

\begin{tabular}{|c|c|c|c|c|c|c|}
\hline \multirow{3}{*}{ Hybrid } & \multirow{3}{*}{$\begin{array}{l}\text { No. of } \\
\text { cells } \\
\text { examined }\end{array}$} & \multicolumn{5}{|c|}{ Meiotic stage } \\
\hline & & \multicolumn{3}{|c|}{ First metaphase } & \multicolumn{2}{|c|}{ First anaphase } \\
\hline & & Bivalents & Univalents & Trivalents & $\begin{array}{l}\text { Chromo- } \\
\text { somes } \\
\text { dividing } \\
\text { late }\end{array}$ & $\begin{array}{l}\text { No. of } \\
\text { cells } \\
\text { examined }\end{array}$ \\
\hline $\begin{array}{l}\text { Prelude } \times \text { Prelude } \\
\text { AABB }\end{array}$ & 169 & $\frac{12.61 \pm 0.08}{(9-15)}$ & $\begin{array}{c}5.75 \pm 0.10 \\
(3-9)\end{array}$ & $\begin{array}{c}1.34 \pm 0.06 * \\
(0-3)^{* *}\end{array}$ & not scored & - \\
\hline $\begin{array}{l}\text { Rescue } \times \text { Rescue } \\
\text { AABB }\end{array}$ & 80 & $\begin{array}{c}13.95 \pm 0.05 \\
(13-14)\end{array}$ & $\begin{array}{c}7.10 \pm 0.01 \\
(7-9)\end{array}$ & - & $\begin{array}{c}5.79 \pm 0.26 \\
(0-7)\end{array}$ & 34 \\
\hline $\begin{array}{l}\text { Thatcher } \times \text { Thatcher } \\
\text { AABB }\end{array}$ & 55 & $\begin{array}{c}13.98 \pm 0.04 \\
(13-16)\end{array}$ & $\begin{array}{c}6.87 \pm 0.19 \\
(3-7)\end{array}$ & $\begin{array}{c}0.05 \pm 0.03 \\
(0-1)\end{array}$ & $\begin{array}{c}4.95 \pm 0.29 \\
(0-7)\end{array}$ & 42 \\
\hline
\end{tabular}

* mean per cell \pm st. error

pentaploid hybrids at MI and AI. At AI of meiosis the fourteen bivalents of the hybrids segregated normally. The behaviour of the univalents, however, was unpredictable in that they either proceeded poleward undivided, or divided late and subsequently were excluded from daughter nuclei, or failed to divide and were lost.

Pentaploid hybrids exhibited significant differences (Table 2) in the mean number of micronuclei per sporocyte $(\mathrm{P}=0.01)$. It is of interest to note that the Thatcher pentaploid which had the highest mean chromosome number in $\mathrm{F}_{2}$ (Table 3) had the lowest mean number of micronuclei per sporocyte.

The number of the univalents per cell dividing late at AI of pentaploid hybrids was scored. The means and standard errors were $4.95 \pm 0.29$ and $5.79 \pm 0.29$ univalents for pentaploid Thatcher and Rescue, respectively. The means were not significantly different from one another indicating that chromosome elimination took place either late in meiosis or that zygotes with intermediate chromosome numbers were eliminated.

The frequency with which gametes containing 14 to 21 chromosomes were expected to form in the hybrids can be calculated as follows: Let $p$ 
be the probability that a given gamete will contain any univalent and $1-p$ the probability that it will not. Furthermore let $n$ equal the number of univalents present in the hybrid. The frequency of gametes carrying zero to $\mathrm{n}$ univalents is given by the terms of the expansion of the binomial

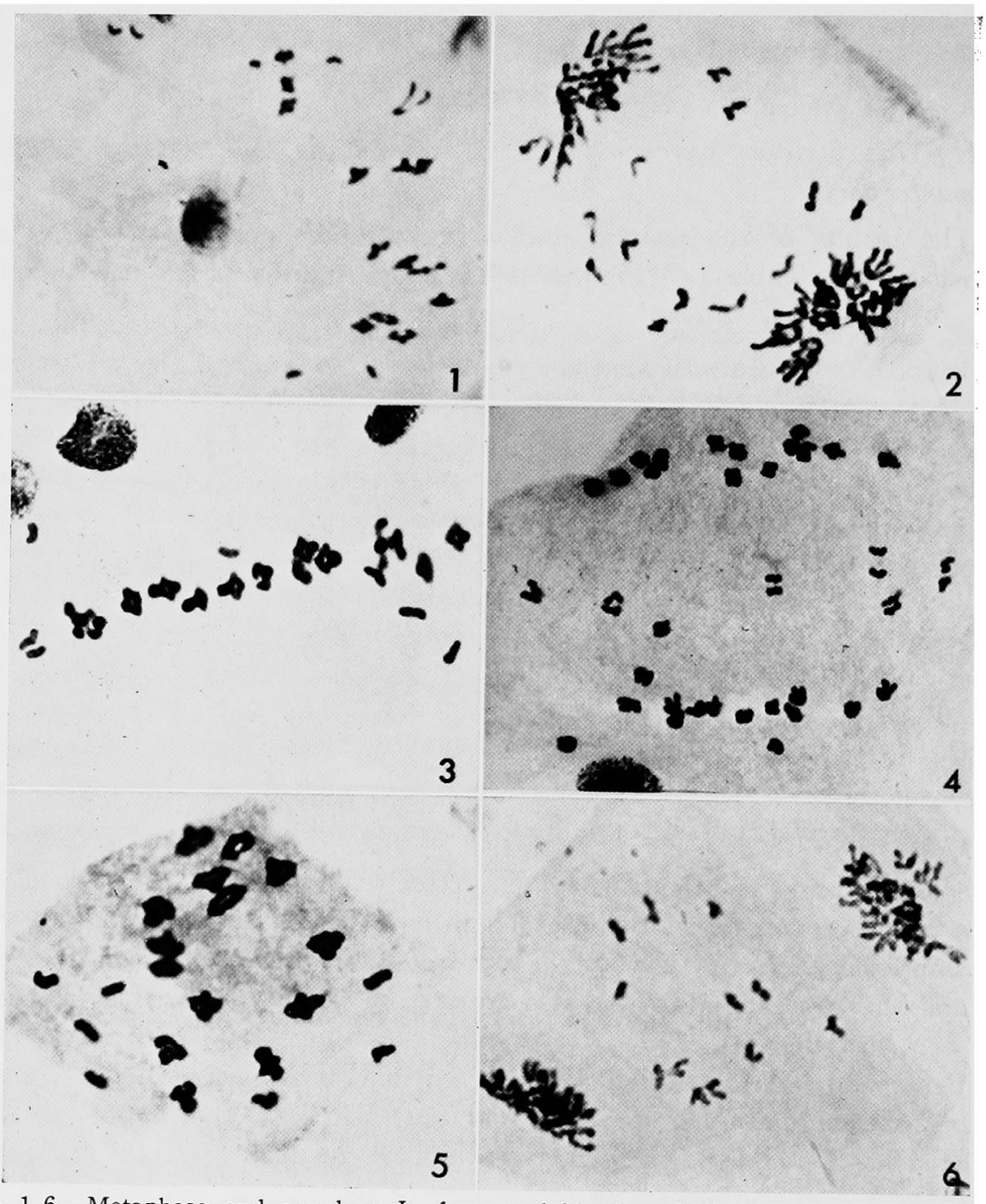

Figs. 1-6. Metaphase and anaphase I of pentaploid wheat hybrids. 1, MI of Prelude $x$ Prelude AABB. Note the trivalent present. 2, AI of Prelude $\times$ Prelude AABB. 3, MI of Rescue $\times$ Rescue $A A B B$. 4, AI of Rescue $\times$ Rescue AABB. 5, MI of Thatcher $\times$ Thatcher AABB. 6 , AI of Thatcher $\times$ Thatcher AABB.

$(p+q)^{n}$, where $q=1-p . \quad$ In the present case, $n$ equals seven for Thatcher and Rescue. If it is assumed that no loss of univalents took place $(p=0.5)$ and that univalents were distributed at random in both micro- and megasporogenesis, the expected frequency of gametes with a particular chromosome number could be determined by expanding the binomial $(0.5+0.5)^{7}$. The 
frequencies of gametes with 14 to 21 chromosomes thus obtained were placed across the top and along the side of a two-way table resulting in a table with 64 cells. The frequency with which a particular zygotic number occurred is

Table 2. Frequency of microspores with 0 to 4 micronuclei, mean number of micronuclei per sporocyte and univalent elimination in pentaploid hybrids derived from hexaploid $(A A B B D D)$ wheats $\times$ their extracted tetraploid (AABB) derivatives

\begin{tabular}{|c|c|c|c|c|c|c|c|c|}
\hline \multirow{2}{*}{ Hybrid } & \multicolumn{6}{|c|}{ Number of micronuclei per sporocyte } & \multirow{2}{*}{$\begin{array}{c}\text { Mean } \pm \text { s.e. } \\
\text { per } \\
\text { sporocyte }\end{array}$} & \multirow{2}{*}{$\begin{array}{l}\text { Univalent } \\
\text { elimination }\end{array}$} \\
\hline & 0 & 1 & 2 & 3 & 4 & Sum & & \\
\hline $\begin{array}{l}\text { Prelude } \times \text { Prelude } \\
\text { AABB }\end{array}$ & 461 & 300 & 39 & 20 & 4 & 824 & $0.55 \pm 0.02$ & $15.74 \%$ \\
\hline $\begin{array}{l}\text { Rescue } \times \text { Rescue } \\
\text { AABB }\end{array}$ & 467 & 273 & 50 & 20 & 10 & 820 & $0.72 \pm 0.02$ & $16.48 \%$ \\
\hline $\begin{array}{l}\text { Thatcher } \times \text { Thatcher } \\
\text { AABB }\end{array}$ & 574 & 80 & 10 & 6 & 6 & 676 & $0.21 \pm 0.02$ & $6.00 \%$ \\
\hline
\end{tabular}

Table 3. Frequency of various somatic chromosome numbers in the $F_{2}$ generaticn of hybrids between hexaploid (AABBDD) wheats and their extracted tetraploid (AABB) derivatives

\begin{tabular}{|c|c|c|c|}
\hline \multirow{2}{*}{$\begin{array}{l}\text { chromosome } \\
\text { number }\end{array}$} & \multicolumn{3}{|c|}{ Hybrid } \\
\hline & $\begin{array}{c}\text { Prelude } \times \text { Prelude } \\
\text { AABB }\end{array}$ & $\begin{array}{c}\text { Rescue } \times \text { Rescue } \\
\text { AABB }\end{array}$ & $\begin{array}{c}\text { Thatcher } \times \text { Thatcher } \\
\text { AABB }\end{array}$ \\
\hline 28 & 44 & 184 & 5 \\
\hline 29 & 45 & 80 & 6 \\
\hline 30 & 32 & 53 & 12 \\
\hline 31 & 19 & 49 & 13 \\
\hline 32 & 19 & 16 & 16 \\
\hline 33 & 16 & 22 & 15 \\
\hline 34 & 11 & 18 & 33 \\
\hline 35 & 18 & 25 & 33 \\
\hline 36 & 7 & 17 & 27 \\
\hline 37 & 2 & 5 & 18 \\
\hline 38 & 4 & 8 & 24 \\
\hline 39 & 2 & 2 & 13 \\
\hline 40 & 3 & 3 & 6 \\
\hline 41 & 3 & 1 & 3 \\
\hline 42 & 5 & 26 & 2 \\
\hline Total & 230 & 509 & 226 \\
\hline $\begin{array}{l}\text { Mean chromo- } \\
\text { some } \pm \text { s.e. }\end{array}$ & $31.45 \pm 0.22$ & $30.91 \pm 0.16$ & $34.80 \pm 0.20$ \\
\hline
\end{tabular}

Chi-square $=382.11,28$ d.f. $(P<0.005)$

the sum of the products of the frequencies of those gametes involved in the combination. This frequency was multiplied by the total shown in each of the rows of Table 3 in order to obtain the expected frequencies. To make the chi-square calculation valid, certain classes were combined so that expected 
values of two or more were obtained. These tests indicated that in both Thatcher and Rescue, the observed frequencies did not fit the expected ones on the basis of random univalent distribution with no chromosomal loss. This was interpreted to mean that univalent loss did in fact occur.

The formula given by Kihara and Matsumura (1942) was used to calculate univalents elimination from male gametes (Table 2). Again assuming that the same univalent elimination took place during both micro- and megasporogenesis, the expected frequencies were calculated and tested for fit to the observed values. Deviation of observed frequencies from expected, however, was significant. Next it was assumed that not all male gametes function with the same frequency but that female gametes are equally functional and furthermore, that independent assortment occurs with no loss of chromosomal material. Once more the observed frequencies did not fit the expected ones.

Table 4. Frequencies of various classes of functional gametes as determined from reciprocal crosses between pentaploid hybrids (AABBDD $\times$ extracted $A A B B$ ) and the parental hexaploids

\begin{tabular}{c|c|c|c|c|c|c}
\hline \hline \multirow{2}{*}{$\begin{array}{c}\text { Chromosome } \\
\text { number }\end{array}$} & \multicolumn{2}{|c|}{ Prelude } & \multicolumn{2}{c|}{ Rescue } & \multicolumn{2}{c}{ Thatcher } \\
\cline { 2 - 6 } \cline { 5 - 7 } & Male & Female & Male & Female & Male & Female \\
\hline 14 & 35 & 19 & 135 & 119 & 12 & 25 \\
15 & 12 & 10 & 35 & 38 & 15 & 28 \\
16 & 9 & 2 & 15 & 12 & 21 & 23 \\
17 & 2 & 4 & 5 & 7 & 33 & 29 \\
18 & 4 & 3 & 7 & 6 & 19 & 21 \\
19 & 3 & 4 & 6 & 7 & 23 & 20 \\
20 & 2 & 3 & 5 & 6 & 20 & 22 \\
21 & 8 & 6 & 39 & 41 & 17 & 14 \\
\hline Total & 75 & 51 & 247 & 236 & 160 & 182 \\
\hline
\end{tabular}

The next step was to test the hypothesis that a considerable loss of univalents took place but those that remained were distributed at random. By assuming that the observed values for the 28 chromosome class in both Rescue and Thatcher was correct, the value of $\mathrm{p}$ should equal the 14th root of 184/509 for Rescue and 5/226 for Thatcher (Table 3). In the manner described above, when the expected frequencies were obtained and tested against the observed ones a poor fit was obtained. Therefore, it was concluded that either the univalents retained were not distributed at random and could not assort independently, or that all classes of gametes were formed according to expectations but they did not function with the same frequency. It became necessary therefore to find the frequency with which the various classes of gametes function in both the male and the female. For this purpose the pentaploid hybrids were crossed reciprocally to their respective hexaploids and the frequencies of gamete classes observed are presented in Table 4. Using these frequencies, the expected zygotic frequencies were calculated in 
the manner described above and the results are shown in Table 5. Chi-square values indicated a satisfactory fit, except in the case of Rescue.

Within each of the three hybrids the gametes functioning on both the male and the female side were compared in an RXC table. Chi-square yalues obtained were $6.47,1.84$ and 8.16 for Prelude, Rescue and Thatcher, respectively. All values were non-significant, indicating that the same proportion of male or female gametes carrying a specific chromosome number

Table 5. Frequencies of somatic chromosome numbers in the $F_{2}$ progenies of pentaploid hybrids as compared to expected on the basis of frequencies of functional gametes determined from reciprocal crosses between pentaploid hybrids and the parental hexaploids

\begin{tabular}{|c|c|c|c|c|c|c|}
\hline \multirow{4}{*}{$\begin{array}{l}\text { Chromo- } \\
\text { some } \\
\text { number }\end{array}$} & \multicolumn{6}{|c|}{ Hybrid } \\
\hline & \multirow{2}{*}{\multicolumn{2}{|c|}{$\frac{\text { Prelude } \times \text { Prelude } A A B B}{\text { Number of plants }}$}} & \multirow{2}{*}{\multicolumn{2}{|c|}{$\begin{array}{c}\text { Rescue } \times \text { Rescue AABB } \\
\text { Number of plants }\end{array}$}} & \multirow{2}{*}{\multicolumn{2}{|c|}{$\begin{array}{c}\text { Thatcher } \times \text { Thatcher AABE } \\
\text { Number of plants }\end{array}$}} \\
\hline & & & & & & \\
\hline & Observed & Calculated & Observed & Calculated & Observed & Calculated \\
\hline 28 & 44 & 42.22 & 184 & 140.62 & 5 & 2.33 \\
\hline 29 & 45 & 36.69 & 80 & 81.16 & 6 & 5.52 \\
\hline 30 & 32 & 22.92 & 53 & 41.34 & 12 & 9.47 \\
\hline 31 & 19 & 18.53 & 49 & 22.09 & 13 & 16.34 \\
\hline 32 & 19 & 10.95 & 16 & 19.72 & 16 & 19.94 \\
\hline 33 & 16 & 17.81 & 22 & 20.08 & 15 & 23.51 \\
\hline 34 & 11 & 15.21 & 18 & 18.22 & 33 & 27.49 \\
\hline 35 & 18 & 30.26 & 25 & 94.59 & 33 & 28.53 \\
\hline 36 & 7 & 12.96 & 17 & 27.82 & 27 & 25.87 \\
\hline 37 & 2 & 6.40 & 5 & 10.77 & 18 & 22.15 \\
\hline 38 & 4 & 4.35 & 8 & 5.17 & 24 & 17.48 \\
\hline 39 & 2 & 2.75 & 2 & 5.17 & 13 & 11.87 \\
\hline 40 & 3 & 3.55 & 3 & 4.79 & 6 & 8.55 \\
\hline 41 & 3 & 2.28 & 1 & 3.83 & 3 & 5.07 \\
\hline 42 & 5 & 3.04 & 26 & 13.96 & 2 & 1.84 \\
\hline Total & 230 & 229.92 & 509 & 509.33 & 226 & 225.96 \\
\hline $\begin{array}{c}\text { Chi-square } \\
\text { value }\end{array}$ & 25.36 & 14 d.f. & 129.71 & 14 d.f. & 15.11 & 14 d.f. \\
\hline
\end{tabular}

functioned on both the male and the female side. Separate analyses of male and female gametic frequencies resulted in a chi-square value of 168.65 and 114.04 for male and female gametes, respectively. Both values were highly significant, indicating that the proportion of the total number of male or female gametes which carried a specific chromosome number differed from variety to variety.

Because the seeds of the $F_{2}$ exhibited some shrivelling, they were separated into two classes, shrivelled and non-shrivelled. Embryos of shrivelled seeds were poorly developed and were consequently cultured on a nutrient 
medium (Norstog and Smith 1963). Chromosome numbers of the resulting plants were determined and compared by a t-test with those resulting from full seeds. No differences in mean chromosome numbers were observed.

\section{Univalent elimination in reciprocal hybrids}

In order to investigate further the possible causes for the differences in the rate of univalent elimination between Thatcher and Rescue (Table 3) the following crosses were made: Rescue $(\mathrm{AABBDD}) \times$ Thatcher $(\mathrm{AABB})$ reciprocally, code numbered hybrid 1 and 2, respectively; Thatcher (AABBDD)

Table 6. Meiotic characteristics of reciprocal hybrids between the extracted tetraploid derivatives $(A A B B)$ of Thatcher and Rescue and their hexaploid counterparts

\begin{tabular}{|c|c|c|c|c|}
\hline \multirow{2}{*}{ Meiotic stage } & \multicolumn{2}{|l|}{ Hybrid 1} & 3 & 4 \\
\hline & $\begin{array}{c}\text { Rescue } \times \\
\text { Thatcher AABB }\end{array}$ & $\begin{array}{c}\text { Thatcher AABB } \\
\times \text { Rescue }\end{array}$ & $\begin{array}{l}\text { Thatcher } \times \\
\text { Rescue AABB }\end{array}$ & $\begin{array}{l}\text { Rescue } A A B B \times \\
\text { Thatcher }\end{array}$ \\
\hline \multicolumn{5}{|l|}{$M I$} \\
\hline Ring bivalents & $\begin{array}{c}10.48 \pm 0.21 * \\
(6-13)^{* *}\end{array}$ & $\begin{array}{c}10.52 \pm 0.22 \\
(6-14)\end{array}$ & $\begin{array}{c}11.27 \pm 0.22 \\
(9-14)\end{array}$ & $\begin{array}{c}10.66 \pm 0.19 \\
(7-13)\end{array}$ \\
\hline Rod bivalents & $\begin{array}{c}1.98 \pm 0.15 \\
(0-6)\end{array}$ & $\begin{array}{l}2.04 \pm 0.16 \\
(0-5)\end{array}$ & $\begin{array}{c}1.33 \pm 0.15 \\
(0-4)\end{array}$ & $\begin{array}{c}1.52 \pm 0.15 \\
(0-4)\end{array}$ \\
\hline Total bivalents & $\begin{array}{c}12.46 \pm 0.19 \\
(10-14)\end{array}$ & $\begin{array}{c}12.56 \pm 0.16 \\
(10-14)\end{array}$ & $\begin{array}{c}12.61 \pm 0.15 \\
(11-14)\end{array}$ & $\begin{array}{c}12.18 \pm 0.15 \\
(9-14)\end{array}$ \\
\hline Univalents & $\begin{array}{c}7.64 \pm 0.15 \\
(7-11)\end{array}$ & $\begin{array}{c}7.18 \pm 0.14 \\
(4-11)\end{array}$ & $\begin{array}{c}7.06 \pm 0.10 \\
(6-9)\end{array}$ & $\begin{array}{l}7.02 \pm 0.09 \\
(5-9)\end{array}$ \\
\hline Trivalents & $\begin{array}{c}0.00 \pm 0.00 \\
(0-1)\end{array}$ & $\begin{array}{l}0.18 \pm 0.05 \\
(0-1)\end{array}$ & $\begin{array}{c}0.21 \pm 0.06 \\
(0-1)\end{array}$ & $\begin{array}{c}0.14 \pm 0.04 \\
(0-1)\end{array}$ \\
\hline Quadrivalents & $\begin{array}{l}0.52 \pm 0.00 \\
(0-1)\end{array}$ & $\begin{array}{c}0.50 \pm 0.07 \\
(0-1)\end{array}$ & $\begin{array}{l}0.47 \pm 0.07 \\
(0-1)\end{array}$ & $\begin{array}{c}0.76 \pm 0.06 \\
(0-1)\end{array}$ \\
\hline \multicolumn{5}{|l|}{ Chromosomes } \\
\hline - lagging at $\mathrm{AI}$ & $\begin{array}{c}5.36 \pm 0.24 \\
(0-8)\end{array}$ & $\begin{array}{l}5.56 \pm 0.22 \\
(0-9)\end{array}$ & $\begin{array}{l}4.96 \pm 0.17 \\
(1-8)\end{array}$ & $\begin{array}{l}5.84 \pm 0.21 \\
(3-8)\end{array}$ \\
\hline - excluded from $T I$ & $\begin{array}{l}1.21 \pm 0.07 \\
(0-5)\end{array}$ & $\begin{array}{c}1.06 \pm 0.10 \\
(0-3)\end{array}$ & $\begin{array}{c}1.00 \pm 0.12 \\
(0-3)\end{array}$ & $\begin{array}{c}1.13 \pm 0.14 \\
(0-3)\end{array}$ \\
\hline - lagging at AII & $\begin{array}{l}4.21 \pm 0.28 \\
(3-7)\end{array}$ & $\begin{array}{l}3.50 \pm 0.21 \\
(1-8)\end{array}$ & $\begin{array}{c}3.19 \pm 0.19 \\
(0-7)\end{array}$ & $\begin{array}{l}3.50 \pm 0.21 \\
(1-6)\end{array}$ \\
\hline $\begin{array}{l}\text { Micronuclei per } \\
\text { sporocyte }\end{array}$ & $\begin{array}{c}0.33 \pm 0.02 \\
(0-3)\end{array}$ & $\begin{array}{l}0.55 \pm 0.02 \\
(0-3)\end{array}$ & $\begin{array}{l}0.41 \pm 0.02 \\
(0-3)\end{array}$ & $\begin{array}{c}0.67 \pm 0.07 \\
(0-3)\end{array}$ \\
\hline
\end{tabular}

$\times$ Rescue $(\mathrm{AABB})$ reciprocally, code numbered hybrid 3 and 4 , respectively. Thus univalent chromosomes present in the $F_{1}$ hybrids 1 and 2 were contributed by Rescue, and in hybrids 3 and 4 they were contributed by Thatcher. It is significant to note that a common genetic background existed in all hybrids.

Hybrid 3 had a significantly higher mean number of ring bivalents per cell relative to the other three hybrids (Table 6). Hybrids 1 and 2 did not differ significantly in rod bivalents per cell but were significantly different from hybrids 3 and 4 . No differences were observed between the hybrids in total number of bivalents or trivalents per cell. Hybrids 1, 2 and 3 
contained significantly fewer quadrivalents per cell relative to hybrid 4 . Hybrids 2, 3 and 4 were significantly different from hybrid 1 in mean univalent number per cell while hybrid 3 differed significantly from hybrid 4 in the number of chromosomes lagging at AI. No significant differences were found in the number of chromosomes excluded from the nucleus at TI. All hybrids were significantly different from one another in the number of chromosomes lagging at AII with hybrid 3 exhibiting the fewest laggards. A significant difference existed between all hybrids in the number of micronuclei per sporocyte with the exception of hybrids 2 and 3.

Table 7. Frequency of various somatic chromosome numbers in the $\mathrm{F}_{2}$ generation of hybrids between hexaploid (AABBDD) wheats and their extracted tetraploid (AABB) derivatives

\begin{tabular}{c|c|c|c|c}
\hline \hline \multirow{2}{*}{$\begin{array}{c}\text { Chromosome } \\
\text { number }\end{array}$} & \multicolumn{4}{|c}{ Hybrid } \\
\cline { 2 - 5 } & $\begin{array}{c}\text { Rescue } \times \text { Thatcher } \\
\text { AABB }\end{array}$ & $\begin{array}{c}\text { Thatcher AABB } \\
\times \text { Rescue }\end{array}$ & $\begin{array}{c}\text { Thatcher } \times \text { Rescue } \\
\text { AABB }\end{array}$ & $\begin{array}{c}\text { Rescue AABB } \times \\
\text { Thatcher }\end{array}$ \\
\hline 28 & 19 & 15 & 11 & 8 \\
29 & 17 & 9 & 13 & 10 \\
30 & 27 & 21 & 17 & 16 \\
31 & 35 & 18 & 21 & 21 \\
32 & 30 & 21 & 12 & 12 \\
33 & 29 & 29 & 14 & 20 \\
34 & 38 & 26 & 14 & 23 \\
35 & 32 & 22 & 12 & 14 \\
36 & 30 & 22 & 11 & 71 \\
37 & 19 & 26 & 7 & 5 \\
38 & 20 & 9 & 6 & -12 \\
39 & 11 & 5 & 4 & - \\
40 & 9 & 5 & - & 2 \\
41 & 4 & 1 & - & 161 \\
42 & - & 236 & 142 & $33.23 \pm 0.25$ \\
\hline Total & 320 & $33.80 \pm 0.20$ & $32.58 \pm 0.26$ & \\
\hline Mean \pm s.e. & $33.57 \pm 0.17$ & & & 5 \\
\hline
\end{tabular}

The analyses of chromosome numbers in the $F_{2}$ population (Table 7) indicated that the use of the hexaploid as female (hybrids 1 and 3) resulted in a significantly greater number of univalents retained in the progeny of hybrid 1 (univalents contributed by Rescue) than in hybrid 3 (univalents contributed by Thatcher). However, when the hexaploids were used as male the differences no longer existed.

In the reciprocal hybrids, namely hybrids 1 and 2 and 3 and 4, respectively the parent which contributed the univalents did not have any effect on their subsequent retention or elimination. 


\section{Discussion}

Hybrids between extracted $A A B B$ tetraploids and their $A A B B D D$ counterparts

In the progeny of the pentaploid hybrids there were more plants with twenty-eight chromosomes than expected on the basis of random univalent segregation. This is in agreement with the results of other workers, although they were using tetraploid wheat species rather than extracted AABB tetraploids (Kihara 1924, Jenkins and Thompson 1930). More recently, Joppa (1967) working with Thatcher $x$ durum crosses also observed an excess of twentyeight chromosome plants. The present data from Thatcher when compared with those of Joppa were found to be homogeneous (Chi-square $=25.49$, with 36 d.f.) indicating that for Thatcher at least, the particular AABB used in the cross did not affect chromosome segregation. When these same data, however, were compared with those of Kerber (1968) they were found to be heterogeneous (Chi-square $=472.88$ with 52 d.f.) indicating that not all extracted AABB tetraploids affect chromosome segregation in the same way. Similar deviations from the expected patterns of chromosome segregation have been reported by other workers and have been attributed to differential functioning of male and female gametes (Thompson and Cameron 1928, Kihara and Matsumura 1942).

The translocation to Prelude AABB (Table 1, Fig. 1) must have taken place during its extraction process. Mello-Sampayo (1968) observed trivalents at MI of hybrids between Chinese Spring ditelocentrics for D genome chromosomes and $\mathrm{Ld} 222$, a durum wheat variety, yet it is known that a translocation is not involved. He attributed this behaviour to homoeologous pairing and it would seem that the same explanation could apply to the trivalents observed in the present material. If this is true, then the pentaploid wheat hybrids could be used as a bridge for the transfer of desirable characters to or from the tetraploid wheats.

The higher mean $\mathrm{F}_{2}$ chromosome number of Thatcher relative to Rescue was correlated with a lower frequency of micronuclei per sporocyte (Table 2). The fact that no differences were found in mean chromosome numbers of plants originating from either full or shrivelled seeds indicated that certain zygotic combinations, which are rare in the progeny, die at an early stage.

\section{Univalent elimination in the reciprocal hybrids}

It seems that no clear-cut association can be made between the differences in cytological behaviour that were observed in the various meiotic stages examined and the final outcome in terms of mean chromosome numbers (Tables 5 and 6). The differences observed indicate that the background genotype or the univalents themselves have little or no effect on univalent elimination. Other factors, i.e. lack of compensation for missing chromosomes 
which in turn hinders further development, might have a decisive effect on the fate of certain zygotic combinations.

\section{Summary}

Chromosome segregation was studied in pentaploid hybrids resulting from crosses between extracted AABB tetraploids and varieties of common wheat. Varietal differences were observed in univalent elimination in the $F_{2}$ progeny. No clear-cut association could be made between the differences in cytological behaviour that were observed in the various meiotic stages examined and the final outcome in terms of mean chromosome numbers in the progeny.

\section{Literature cited}

Jenkins, J. A. and Thompson, W. P. 1930. Chromosome conditions in the second and third generations of pentaploid wheat hybrids. Can. J. Research C. 2: 162-170.

Joppa, L. R. 1967. Chromosome segregation in a Triticum aestivum L. em. Thell by $T$. durum Dest. cross and the production of $\mathrm{D}$ genome addition lines. Unpublished $\mathrm{Ph}$. D. thesis. Montana State University, Bozeman, Montana.

Kaltsikes. P. J., Evans, L. E., and Bushuk, W. 1968. Durum-type wheat with high breadmaking quality. Science 159: 211-213.

Kerber, E. R. 1964. Wheat: Reconstitution of the tetraploid component (AABB) of hexaploids. Science 143: 253-255.

- 1968. Personal communication.

Kihara, H. and Matsumura, S. 1942. Ueber die Univalentenelimination in den verschiedenchromosomigen Nachkommen des pentaploiden Triticum-Bastards. Japan. J. Botany. 12: $225-236$.

Love, R. M. 1940. Chromosome behaviour in a plant breeder's sample of pentaploid wheat hybrid derivatives. Can. J. Res., C. 18: 415-434.

Mello-Sampayo, T. 1968. Personal Communication.

Norstog, K. and Smith, J. E. 1963. Culture of small barley embryos on defined media. Science 142: 1655-1656.

Steel, R. G. D. and Torrie, J.H. 1960. Principles and procedures of statistic. McGraw Hill, New York, N. Y.

Thompson, W. P. 1934. The causes of the cytological results obtained in a wheat species cross. Can. J. Res. 10: 190-198.

- and Cameron, D. R. 1928. Chromosome numbers in functioning germ cells of species hybrids in wheat. Genetics 13: 456-469. 